\title{
Phosphorus in Oil Palm Cultivated in the Oriental Amazon
}

\author{
Ismael de Jesus Matos Viegas \\ Universidade Federal Rural da Amazônia, Campus Capanema, Pará, Brasil. \\ E-mail: matosviegas@hotmail.com \\ Magda do Nascimento Farias (Corresponding Author) \\ Universidade Federal Rural da Amazônia, Campus Capitão Poço, Pará, Brasil. \\ E-mail: magda.fariasagro@gmail.com
}

Eric Victor de Oliveira Ferreira

Universidade Federal Rural da Amazônia, Campus Capitão Poço, Pará, Brasil.

E-mail: ericsolos@yahoo.com.br

Henrique da Silva Barata

Universidade Federal Rural da Amazônia, Campus Belém, Pará, Brasil.

E-mail: henriquebarata2000@gmail.com

Heráclito Eugênio Oliveira da Conceição

Universidade Federal Rural da Amazônia, Campus Capitão Poço, Pará, Brasil.

E-mail: agroheraclito@yahoo.com.br

Jessivaldo Rodrigues Galvão

Universidade Federal Rural da Amazônia, Campus Belém, Pará, Brasil.

E-mail: jessigalvao50@gmail.com

Diocléa Almeida Seabra Silva

Universidade Federal Rural da Amazônia, Campus Capanema, Pará, Brasil.

E-mail: dioclea.seabra@ufra.edu.br

Received: May 12, 2021 Accepted: June 14, $2021 \quad$ Published: June 16, 2021 


\begin{abstract}
Amazon soils have a low phosphorus (P) availability and few studies have investigated nutrition of palm oil plantations. This study assessed the effects of $\mathrm{P}$ nutrition on oil palm organs according to plant age. The experiment was carried out under field conditions, at the enterprise Agropalma S/A, in the municipality of Tailândia, Pará State, Brazil. The experimental design used was completely randomized with four replications and comprised seven treatments: plants age $(2,3,4,5,6,7$, and 8 years of planting). We evaluated $\mathrm{P}$ concentration, accumulation, and exportation in plant components (leaflets, petioles, stipe, rachis, palm heart, arrows, male inflorescences, peduncles, spikelets, and fruits). Palm heart $\left(10.9 \mathrm{~g} \mathrm{~kg}^{-1}\right)$ and male inflorescence $\left(3.8 \mathrm{~g} \mathrm{~kg}^{-1}\right)$ showed the highest $\mathrm{P}$ concentrations in the vegetative and reproductive organs, respectively. On the other hand, the largest $\mathrm{P}$ accumulations were observed in the stipe $\left(159 \mathrm{~g} \mathrm{plant}^{-1}\right)$ and fruits $\left(59 \mathrm{~g} \mathrm{plant}^{-1}\right)$, increasing from the $3^{\text {rd }}$ year of age of the plants. Bunches exported the largest $\mathrm{P}$ amounts $\left(81 \mathrm{~g} \mathrm{plant}^{-1}\right)$, especially in older plants. The oil palm immobilizes $\left(24 \mathrm{~kg} \mathrm{ha}^{-1}\right)$ and recycles $\left(23 \mathrm{~kg} \mathrm{ha}^{-1}\right) \mathrm{a}$ large amount of $\mathrm{P}$, more than it exports $\left(12 \mathrm{~kg} \mathrm{ha}^{-1}\right) \mathrm{P}$.
\end{abstract}

Keywords: Elaeis guineenses, oilseed, concentration, accumulation, nutritional diagnosis

\title{
1. Introduction
}

Oil palm (Elaeis guineenses Jacq.) is indigenous to Africa and an important source of vegetable oil widely used in the cosmetic and biodiesel industries (LEBID; HENKES, 2015). In economic terms, oil palm has a useful life of 25 years. Oil palm crops reach the maximum productive potential eight years after planting with an output of $25 \mathrm{t} \mathrm{ha}^{-1}$ year $^{-1}$, resulting in 4 to $6 \mathrm{t} \mathrm{ha}^{-1}$ year $^{-1}$ of oil production (NABUN et al., 2017; CRUZ FILHO et al., 2019).

The Amazon region has the largest oil palm cultivated areas in Brazil, covering 38,912 ha, constituting the main matrix for palm oil production in the country (NAHUN et al., 2020). Despite favorable climatic conditions in this region (LOPES and GUILHERME, 2007), several factors still limit the crop full development, such as adequate nutrition, which lead to low average of oil palm yield (17 $\left.\mathrm{t} \mathrm{ha}^{-1}\right)$ (HOMMA and REBELLO, 2020).

In the Pará State (Brazil), Oxisols and Argisols predominate (GAMA et al., 2020) and these soils have high acidity, high aluminum (Al) saturation, and low fertility, requiring appropriate correction and fertilization to make crop production viable (FERNANDES et al., 2013). Phosphorus (P) is an essential nutrient for plant growth and functioning, ranked as the second most limiting nutrient to agricultural production (MOHIDIN et al., 2015). In tropical soils, $\mathrm{P}$ has low availability and is considered the most limiting factor for plant growth (TAN et al., 2010), as observed for oil palm crops in the Brazilian Amazon (RODRIGUES, 1993).

$\mathrm{P}$ is essential in practically all metabolic processes, namely photosynthesis, energy transfer, macromolecular biosynthesis, signal transduction, and respiration (KHAN et al., 2010; BUCHER et al., 2018). Thus, $\mathrm{P}$ absorption by oil palm is crucial for crop yield and dry matter (DM) accumulation in the plant (SHEN et al. 2011; NING et al., 2013). Oil palm has great 


\section{Macrothink

and varied nutritional demands, depending on yield, genotype, spacing, palm age, soil type, soil conditions, and climate (WOITTIEZ et al., 2017). For a production of $17 \mathrm{t} / \mathrm{ha}$ of bunches of fresh fruits, oil palm exports $25.5 \mathrm{~kg}$ of $\mathrm{P}_{2} \mathrm{O}_{5}$ (VIEGAS and BOTELHO, 2000). However, few studies have investigated $\mathrm{P}$ influence on oil palm nutrition, which is important for crop yield. This study assessed the effects of $\mathrm{P}$ nutrition on organs of oil palm trees according to the planting age.

\section{Material and Methods}

\subsection{Study Site}

The experiment was carried out under field conditions, at the enterprise Agropalma S/A, in the Northeast of Pará State, in the municipality of Tailândia ( $2^{\circ} 56^{\prime} 50^{\prime \prime} \mathrm{S}$ and $48^{\circ} 57^{\prime} 12^{\prime \prime} \mathrm{W}$ ), Brazil. The climate in this region is Ami type (rainy tropical) (Köppen classification), with an average annual temperature $26.5^{\circ} \mathrm{C}$, annual precipitation $2,400 \mathrm{~mm}$, and air relative humidity $84 \%$. A gauge installed at Agropalma was used to monitor rainfall during the experimental period, which averaged 2,409 $\mathrm{mm}_{\text {year }}^{-1}$ (Figure 1).

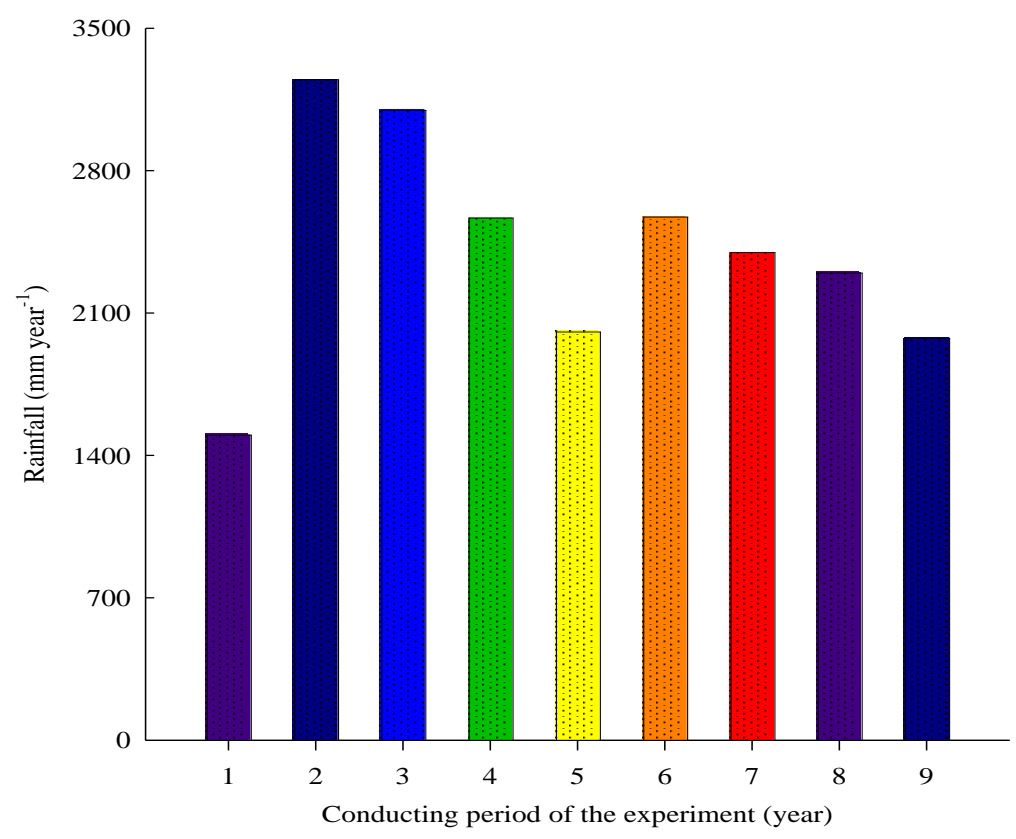

Figure 1. Rainfall in the area of enterprise Agropalma during the experimental period

The soil in the experimental site is classified as a dystrophic Yellow Oxisol, acidic, with low natural chemical fertility and medium texture (RODRIGUES et al., 2005; SANTOS et al., 2018). Soil samples (0-0.3 m) were taken during the plant collection period, composed of four simple samples each, collected between the planting lines for each age of the plants. Then, the samples were sent to the laboratory of the Soil Science Department of Luiz de Queiroz College of Agriculture for chemical characterization (Table 1). The physical analyses (Table 1) were carried out at the Agroforestry Research Center of the Eastern Amazon Embrapa. 
Table 1. Chemical and physical characteristics of soil samples $(0-30 \mathrm{~cm})$ from plantations with different ages of oil palm plants

Features

Plants age (years)

\begin{tabular}{|c|c|c|c|c|c|c|c|}
\hline \multirow{4}{*}{$\begin{array}{c}\mathrm{pH}\left(\mathrm{CaCl}_{2}\right) \\
\mathrm{K}^{*}\left(\mathrm{cmol}_{\mathrm{c}} \mathrm{dm}^{-3}\right)\end{array}$} & 2 & 3 & 4 & 5 & 6 & 7 & 8 \\
\hline & 4.3 & 4.4 & 4.1 & 4.0 & 4.0 & 4.3 & 4.0 \\
\hline & & & & & & & \\
\hline & 0.07 & 0.06 & 0.05 & 0.07 & 0.05 & 0.05 & 0.06 \\
\hline $\mathrm{Ca}^{*}\left(\mathrm{cmol}_{\mathrm{c}} \mathrm{dm}^{-3}\right)$ & 0.7 & 0.7 & 0.9 & 0.8 & 0.7 & 0.7 & 0.6 \\
\hline $\mathrm{Mg}^{*}\left(\mathrm{cmol}_{\mathrm{c}} \mathrm{dm}^{-3}\right)$ & 0.4 & 0.2 & 0.2 & 0.3 & 0.3 & 0.3 & 0.3 \\
\hline $\mathrm{Al}\left(\mathrm{cmol}_{\mathrm{c}} \mathrm{dm}^{-3}\right)$ & 0.4 & 0.3 & 0.3 & 0.5 & 0.8 & 0.4 & 0.6 \\
\hline $\mathrm{H}+\mathrm{Al}^{* *}\left(\mathrm{cmolc}_{\mathrm{c}} \mathrm{dm}^{-3}\right)$ & 3.4 & 2.8 & 3.1 & 3.8 & 3.4 & 2.6 & 3.4 \\
\hline $\mathrm{SB}\left(\mathrm{cmol}_{\mathrm{c}} \mathrm{dm}^{-3}\right)$ & 1.17 & 0.96 & 1.15 & 1.17 & 1.05 & 1.05 & 0.96 \\
\hline $\mathrm{P}^{*}\left(\mathrm{mg} \mathrm{dm}^{-3}\right)$ & 4 & 6 & 5 & 6 & 6 & 6 & 8 \\
\hline $\mathrm{V}(\%)$ & 24 & 24 & 26 & 22 & 22 & 27 & 20 \\
\hline O.M*** $\left(\mathrm{g} \mathrm{dm}^{-3}\right)$ & 1.6 & 2.3 & 1.5 & 1.9 & 2.0 & 2.1 & 1.8 \\
\hline Coarse sand (\%) & 45 & 32 & 50 & 37 & 38 & 34 & 51 \\
\hline Fine sand $(\%)$ & 28 & 30 & 19 & 31 & 21 & 32 & 23 \\
\hline Silt (\%) & 4 & 16 & 8 & 10 & 8 & 10 & 6 \\
\hline Clay $(\%)$ & 23 & 22 & 23 & 22 & 33 & 24 & 20 \\
\hline
\end{tabular}

*Extracted with ion Exchange resin. $\quad$ ** Method SMP. $\quad * * *$ Colorimetric method.

The oil palm plants are from the commercial hybrid Tenera (Dura x Psífera), aged 2 to 8 years, grown in the $9 \times 9 \mathrm{~m}$ spacing, in an equilateral triangle, totaling 143 plants/ ha. Table 2 shows information on plant age, yield, and fertilizers. 
Table 2. Plants age, yield, and mineral fertilization of oil palm trees

\begin{tabular}{|c|c|c|c|c|c|c|c|}
\hline \multirow{3}{*}{$\begin{array}{l}\text { Plant age } \\
\text { (Years) }\end{array}$} & \multirow{3}{*}{$\begin{array}{l}\text { Yield } \\
\mathrm{tha}^{-1}\end{array}$} & \multicolumn{6}{|c|}{ Mineral fertilization } \\
\hline & & $\mathrm{N}$ & $\mathrm{P}_{2} \mathrm{O}_{5}$ & $\mathrm{~K}_{2} \mathrm{O}$ & $\mathrm{Mg}$ & $\mathrm{S}$ & $\mathrm{H}_{3} \mathrm{BO}_{3}$ \\
\hline & & \multicolumn{5}{|c|}{----------------------- g/plant } & \\
\hline 2 & - & 35 & 60 & 60 & - & 24 & - \\
\hline 3 & 1.5 & 18 & $77 * *$ & 154 & - & - & - \\
\hline 4 & 7.0 & 56 & 115 & 300 & 60 & 45 & - \\
\hline 5 & 9.0 & 97 & 336 & 240 & 60 & 45 & - \\
\hline 6 & 15.0 & 135 & 470 & 335 & 77 & 58 & - \\
\hline 7 & 19.0 & 135 & 470 & 335 & 102 & 58 & 50 \\
\hline 8 & 20.0 & 160 & 384 & 324 & 68 & 52 & 60 \\
\hline
\end{tabular}

** Application of $500 \mathrm{~kg} / \mathrm{ha}$ of phosphine (rock phosphate).

The following criteria were used to select homogeneous plants: same plot, age, uniformity, development, nourishment, health, and with good yield. After plant identification, stem circumference and plant height were measured from the base of leaf 33, corresponding to the height of the ripe bunch to be harvested.

\subsection{Study Experimental Design and Analysis of Variables}

The experimental design used was completely randomized with four replications and comprised seven treatments: plant ages $(2,3,4,5,6,7$, and 8 years of planting). Each plant corresponded to an experimental unit. The sampling process consisted of separating leaflets, petioles, rachis, palm heart, arrows, stipe, male inflorescences, peduncles, spikelets, and fruits in each plant. We obtained fresh matter (FM) and representative samples of each plant component.

Samples of the collected plant material were sent to the laboratory, where a sub-sample (SS) was removed, stored in a paper bag and dried in a forced air circulation oven $\left(70{ }^{\circ} \mathrm{C}\right)$ until a constant mass was reached. Subsequently, we quantified the dry mass of sub-samples (DMSS) of the different vegetative organs collected. FM, SS, and DMSS data for each material were placed in the equation $\left(\mathrm{DM}=\mathrm{DMSS}^{*} \mathrm{FM} / \mathrm{SS}\right)$ to obtain the dry matter (DM) content of each plant part. $\mathrm{P}$ was determined after the plant tissue was ground through a Willey mill and by colorimetry using the vanado-immobilized ammonium method (MALAVOLTA et al., 1997). 


\section{Macrothink

The effects of the treatments were evaluated in terms of concentration, accumulation, and exportation of $\mathrm{P}$ in each plant organ. The accumulated quantities in the different oil palm components for each age were estimated from the $\mathrm{P}$ concentration in the plant tissue and dry mass values. The immobilized amounts of $\mathrm{P}$ were obtained by adding the accumulated stipe, palm heart, and arrows, while the recycled amounts were obtained from leaflets, rachis, petioles, and inflorescences. After carrying out $\mathrm{P}$ evaluations for each organ of the oil palm plant, the data were subjected to the analysis of variance (F test; $p<0.05)$ and adjustments were made to regression models using the Sisvar statistical software (FERREIRA, 2011).

\section{Results}

Plant age influenced $\mathrm{P}$ concentrations in different oil palm organs (Figure 2). In vegetative organs, palm heart showed the highest concentration $\left(10.9 \mathrm{~g} \mathrm{~kg}^{-1}\right)$ in the eighth year, while rachis had the lowest value $\left(0.2 \mathrm{~g} \mathrm{~kg}^{-1} \mathrm{P}\right)$ in the second, third, and fourth years of life (Figure $2 b)$. An increasing quadratic response was observed in $\mathrm{P}$ concentration in vegetative organs, petiole, palm heart, and arrows, at different plant ages (Figures $2 \mathrm{a}$ and $2 \mathrm{~b}$ ). On the other hand, $\mathrm{P}$ concentration in rachis and leaflets responded to the negative quadratic model for plant age (Figures 2a and 2b), while plant age did not influence P concentration in stipe (Figure 2a).

For reproductive plant organs, male inflorescence obtained the highest $\mathrm{P}$ concentration $(3.8 \mathrm{~g}$ $\left.\mathrm{kg}^{-1}\right)$ in the sixth year, while spikelets had the lowest concentration $\left(0.4 \mathrm{~g} \mathrm{~kg}^{-1}\right)$ in the fourth year of age (Figures $2 \mathrm{c}$ and $2 \mathrm{~d}$ ). The $\mathrm{P}$ concentration showed a quadratic response increase in male inflorescence and fruits according to plant age. In peduncle and spikelets, $\mathrm{P}$ concentration reached its maximum value in the sixth and seventh years, respectively (Figures $2 c$ and $2 d$ ). 


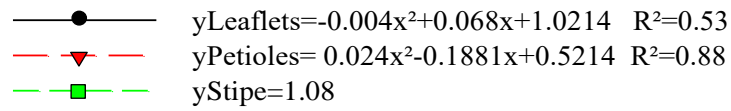

(a)
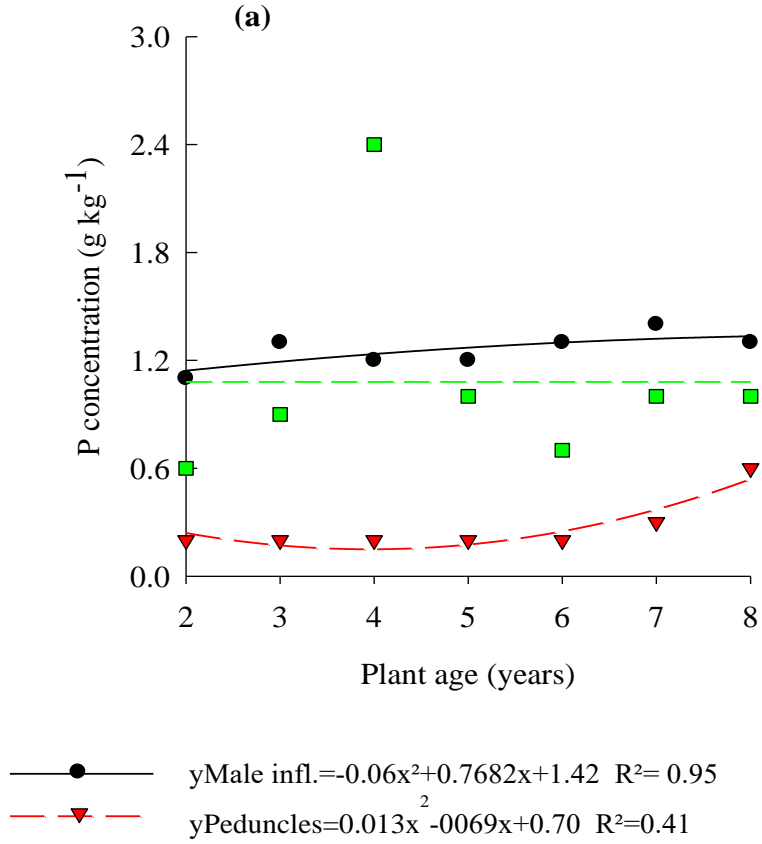

yMale infl. $=-0.06 \mathrm{x}^{2}+0.7682 \mathrm{x}+1.42 \mathrm{R}^{2}=0.95$

$\mathrm{yPeduncles}=0.013 \mathrm{x}-0069 \mathrm{x}+0.70 \mathrm{R}^{2}=0.41$

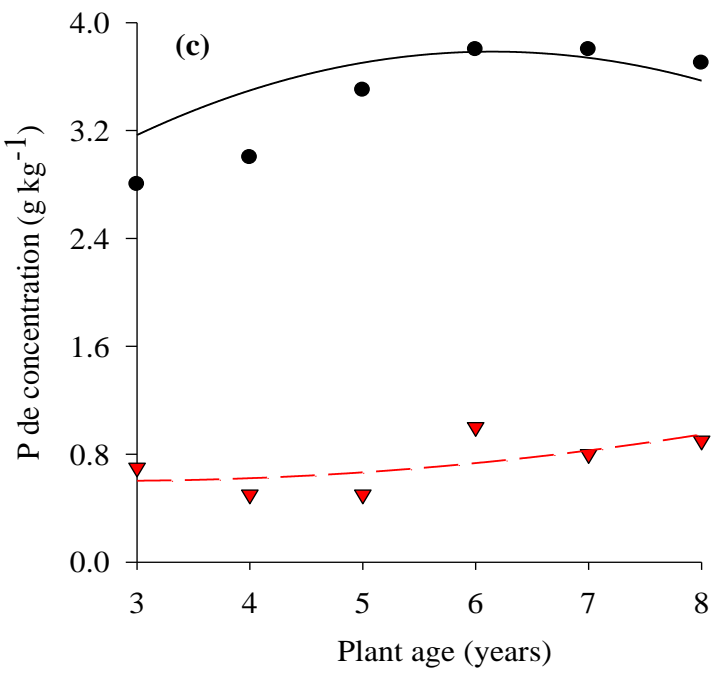

$\longrightarrow$ yRachis $=-0.001 \mathrm{x}^{2}+0.07 \mathrm{x}+0.01 \mathrm{R}^{2}=0.66$ yArrows $=0.073 x^{2}-0.74 x+3.37 R^{2}=0.63$ yPalm heart $=0.24 x^{2}-1.58 x+8.12 R^{2}=0.87$

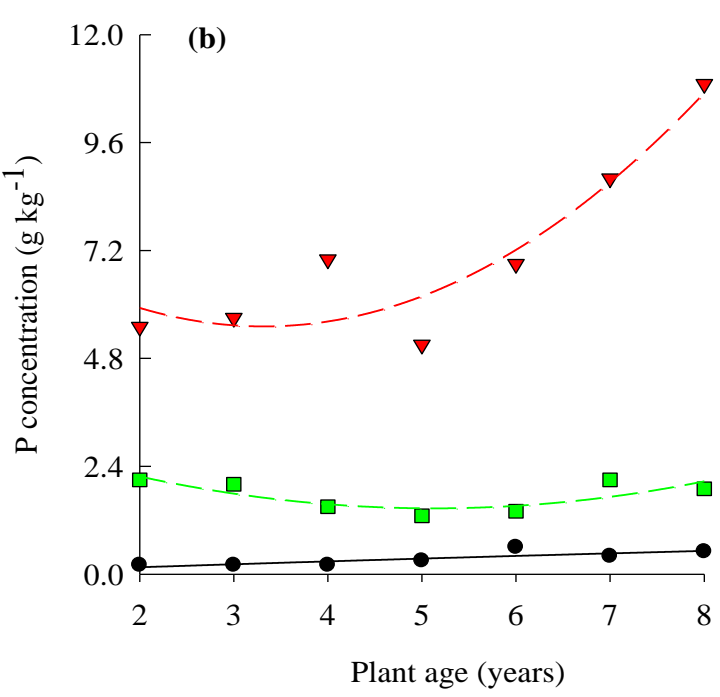

$\begin{array}{ll}\nabla- & \begin{array}{l}\text { ySpikelets }=0.0054 \mathrm{x}^{2}-0.010 \mathrm{x}+0.43 \quad \mathrm{R}^{2}=0.46 \\ \text { yFruits }=-0.19 \mathrm{x}^{2}+2.13 \mathrm{x}-3.28 \mathrm{R}^{2}=0.29\end{array}\end{array}$

(d)

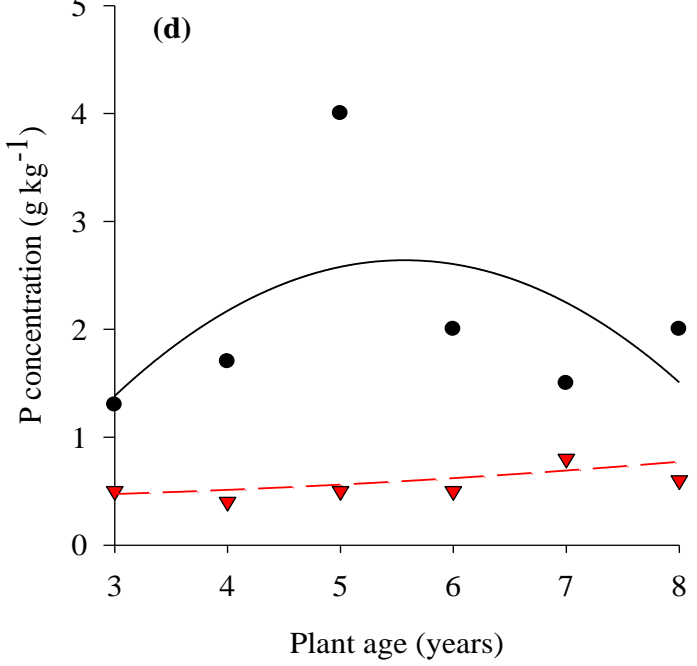

Figure 2. P concentration in leaflets, petioles, and stipe (a), in rachis, palm heart, and arrow (b), in male inflorescence and peduncle (c), and in spikelets and fruits (d), according to oil palm

All ages showed a variation in $\mathrm{P}$ concentrations in different organs of oil palm plants, mainly palm heart (114\%), with 5.1-10.9 $\mathrm{g} \mathrm{kg}^{-1}$ of $\mathrm{P}$ (Table 3). On the other hand, leaflets showed less variation $(27 \%)$ in $\mathrm{P}$ concentrations (1.1-1.4 $\left.\mathrm{g} \mathrm{kg}^{-1}\right)$. 


\section{Macrothink}

Table 3. Variation in P concentrations in different plant organs (leaflets, petioles, rachis, palm heart, arrows, stipes, male inflorescences, peduncles, spikelets, and fruits) of oil palm trees

\begin{tabular}{ccc}
\hline Plants organs & P concentration $\left(\mathrm{g} \mathrm{kg}_{-}{ }^{1}\right)$ & Variation $(\%)$ \\
\hline Leaflets & $1.1-1.4$ & 27 \\
Petioles & $0.2-0.6$ & 67 \\
Rachis & $0.2-0.6$ & 114 \\
Palm heart & $5.1-10.9$ & 62 \\
Arrows & $1.3-2.1$ & 75 \\
Stipe & $0.6-2.4$ & 36 \\
Male Inflorescences & $2.8-3.8$ & 80 \\
Peduncles & $5.0-1.0$ & 50 \\
Spikelets & $0.4-0.8$ & 54 \\
Fruits & $1.3-2.0$ & 50 \\
\hline
\end{tabular}

$\mathrm{P}$ accumulation in the crown (leaflets, petioles, rachis and arrows), stipe, bunches and male inflorescence shows a higher value in stipe (159 $\mathrm{g} \mathrm{plant}^{-1}$ of $\left.\mathrm{P}\right)$, corresponding to $39 \%$ of the total plant in the eighth year. The lowest accumulation $\left(0.89 \mathrm{~g} \mathrm{plant}^{-1}\right)$ occurred in bunches in the third year, representing 3.2\% of total plant (Figures $3 \mathrm{a}$ and $3 \mathrm{~b}$ ). P accumulation in all organs increased with plant age. Stipe and bunches displayed a quadratic behavior, while crown and male inflorescence had a linear response to plant ages. Thus, $\mathrm{P}$ accumulation occurred in the order: stipe> crown> bunches> male inflorescence (Figures $3 \mathrm{a}$ and $3 \mathrm{~b}$ ). 

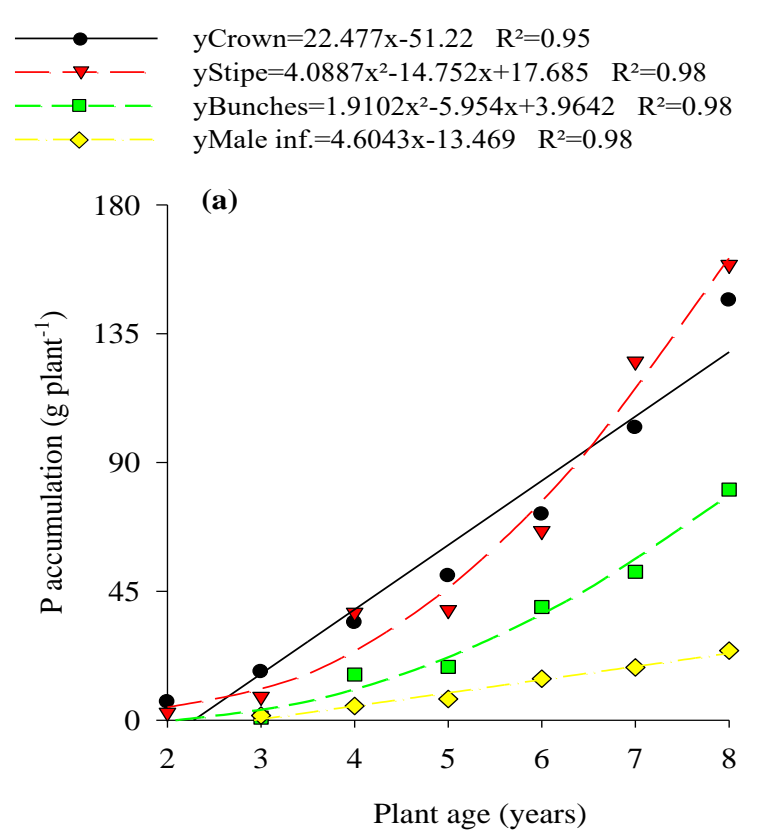
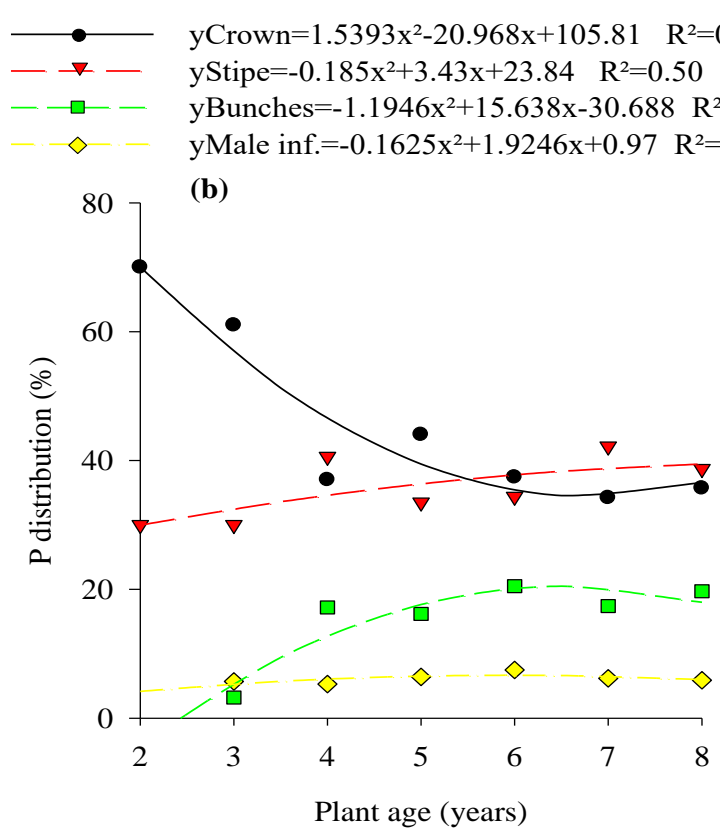

Figure 3. Accumulation (a) and percentage distribution (b) of $\mathrm{P}$ in crown, stipe, bunches, and male inflorescences, according to oil palm age

In the eighth year, $\mathrm{P}$ had an accumulation of $147 \mathrm{~g}$ plant ${ }^{-1}$ in crown, equivalent to $21 \mathrm{~kg} \mathrm{ha}^{-1}$ of $\mathrm{P}$ (143 plants $\left.\mathrm{ha}^{-1}\right)$. $\mathrm{P}$ accumulation in vegetative organs showed a maximum value in stipe $\left(159 \mathrm{~g} \mathrm{plant}^{-1}\right)$ and a minimum value in palm heart $\left(0.46 \mathrm{~g}\right.$ plant $\left.^{-1}\right)$ in the eighth and second years, respectively. Quadratic equations explained $\mathrm{P}$ accumulations in all organs, increasing over plant ages (Figures 4a and 4b).

For reproductive organs, fruits showed the highest $\mathrm{P}$ accumulation (59 $\left.\mathrm{g} \mathrm{plant}^{-1}\right)$, while peduncle had the smallest accumulation (1.3 $\left.\mathrm{g} \mathrm{plant}^{-1}\right)$ in the eighth and third years, respectively. The effects of this relationship were explained by the increases of quadratic equations according to plant ages (Figures $4 \mathrm{c}$ and $4 \mathrm{~d}$ ). The following increasing order of $\mathrm{P}$ accumulation was observed in oil palm plants: stipe $>$ leaflets $>$ fruits $>$ petioles $>$ male inflorescences $>$ rachis $>$ spikelets $>$ arrows $>$ palm heart $=$ peduncles (Figure 4$)$. 

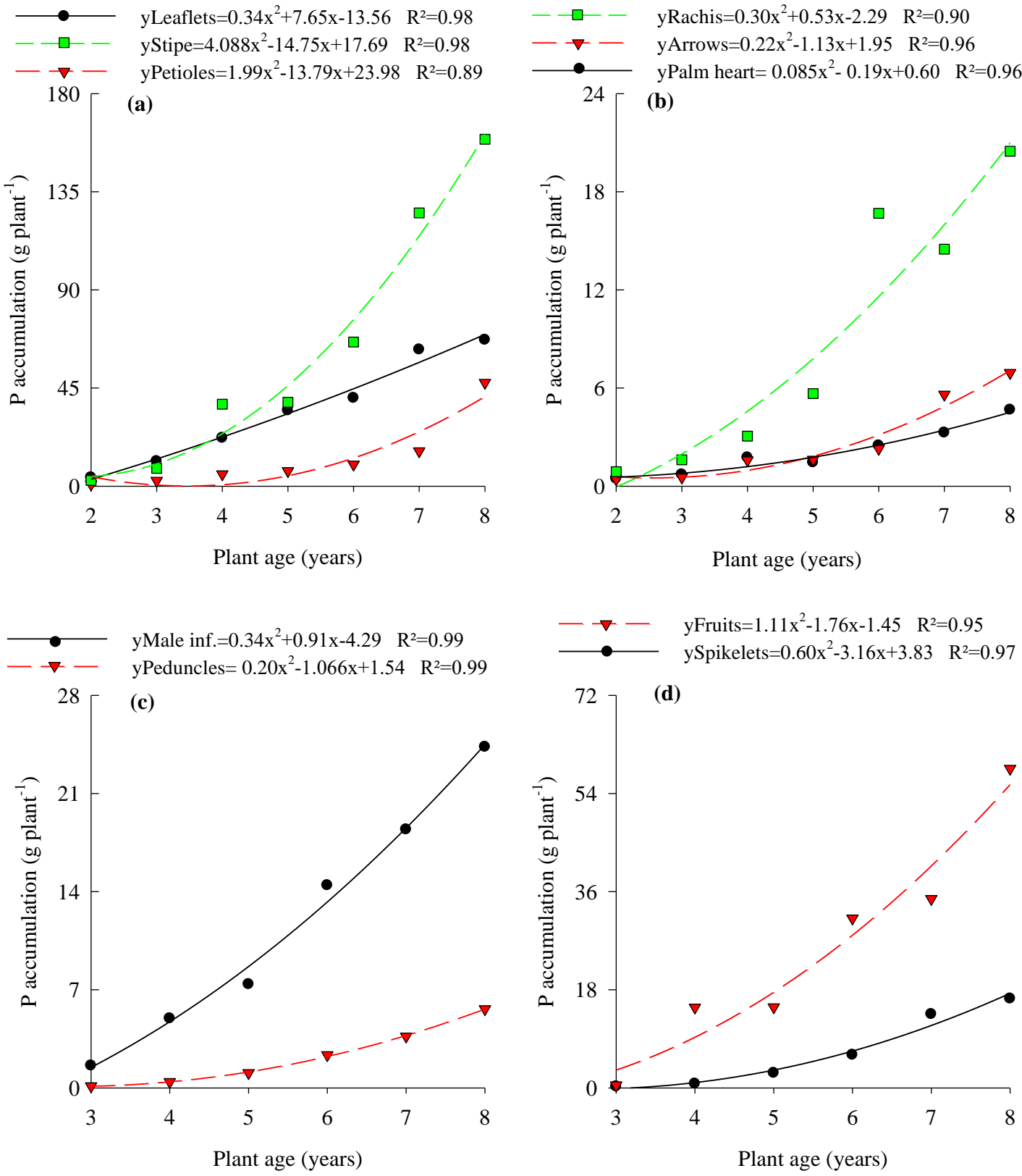

Figure 4. P accumulation in leaflets, petioles, and stipe (a), in rachis, palm heart, and arrows (b), in male inflorescences and peduncles (c), and in spikelets and fruits (d), according to oil palm ages

The highest total $\mathrm{P}$ accumulation was observed in the eighth year, reaching $411 \mathrm{~g} \mathrm{plant}^{-1}$, equivalent to $59 \mathrm{~kg} \mathrm{ha}^{-1}$, with an increasing quadratic response with plant ages (Figures 5a and $5 b)$. 

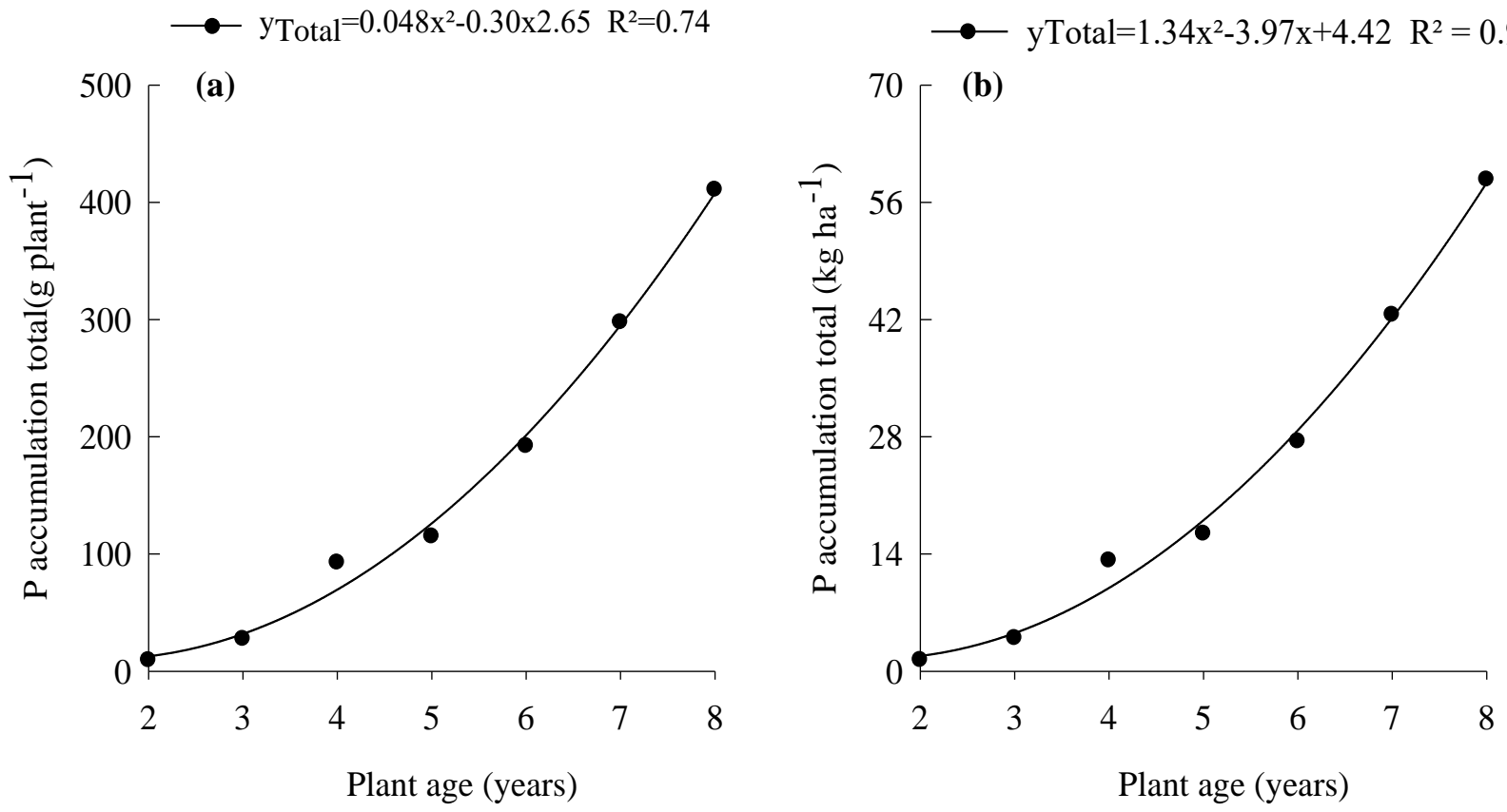

Figure 5. Total $\mathrm{P}$ accumulation per plant (a) and total $\mathrm{P}$ accumulation per area (b) in oil palm, according to plant age

The percentage increase in total $\mathrm{P}$ extraction in terms of oil palm age increased according to plant growth (Figure 6). The third year showed the lowest percentage increase (296\%) in total $\mathrm{P}$ accumulation, while the eighth year had the maximum accumulation (4414\%). 


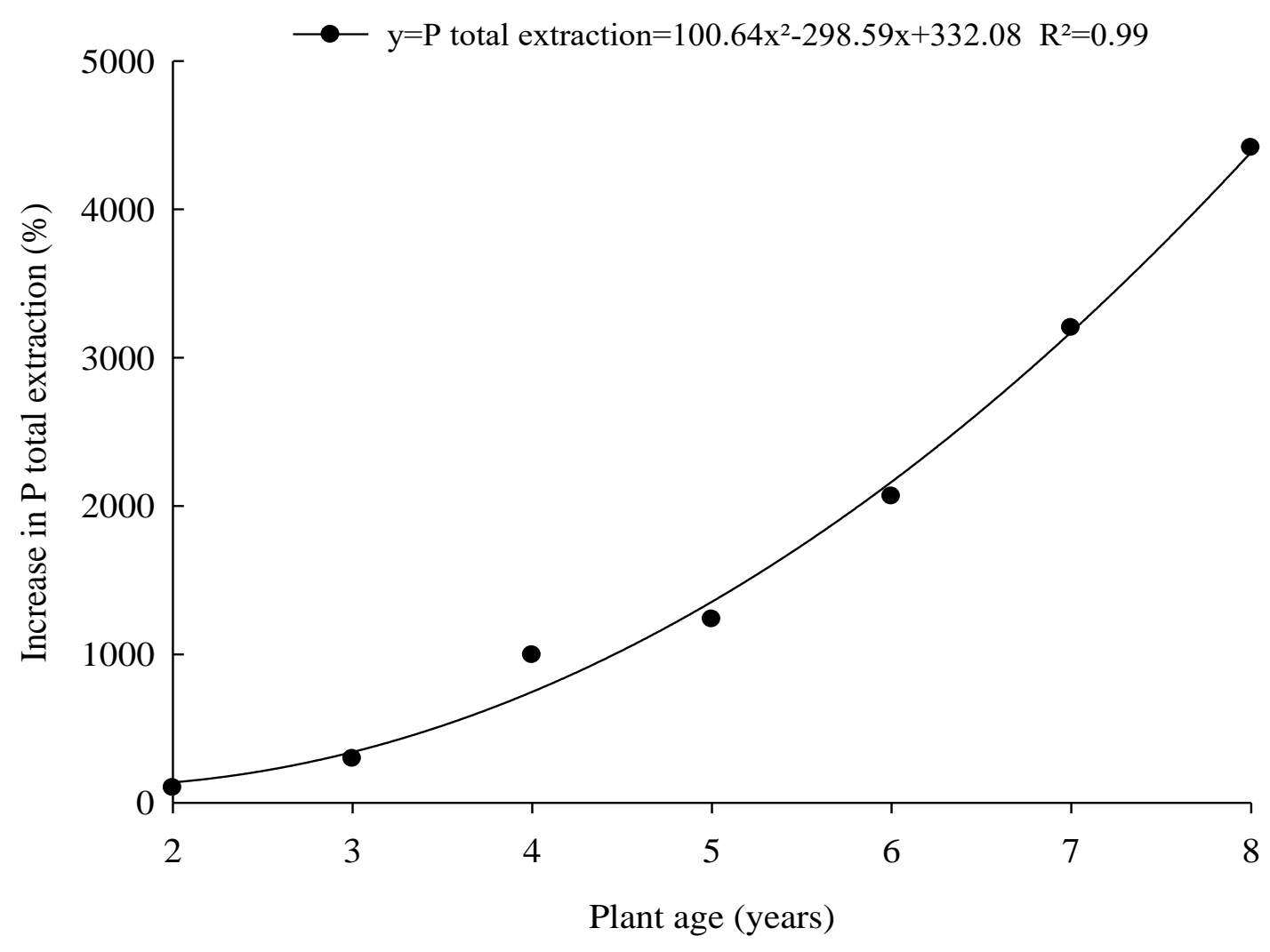

Figure 6. Percentage increase in total $\mathrm{P}$ extraction due to oil palm age

The highest $\mathrm{P}$ exports were observed for bunches $\left(81 \mathrm{~g} \mathrm{plant}^{-1}\right)$ in the eighth year and the lowest for fruits $\left(0.5 \mathrm{~g} \mathrm{plant}^{-1}\right)$ in the third year, corresponding, respectively, to $11.52 \mathrm{~kg} \mathrm{ha}^{-1}$ and $0.07 \mathrm{~kg} \mathrm{ha}^{-1}$ (Figures $7 \mathrm{a}$ and $7 \mathrm{~b}$ ). The $\mathrm{P}$ export showed a quadratic increase to plant age (Figure 7). The percentage variation in $\mathrm{P}$ export by peduncle occurred from 2.7 to $14.8 \%$, from 4.8 to $28.5 \%$ in spikelets, and from 56.8 to $92.5 \%$ in fruits (Figure $7 \mathrm{c}$ ). 


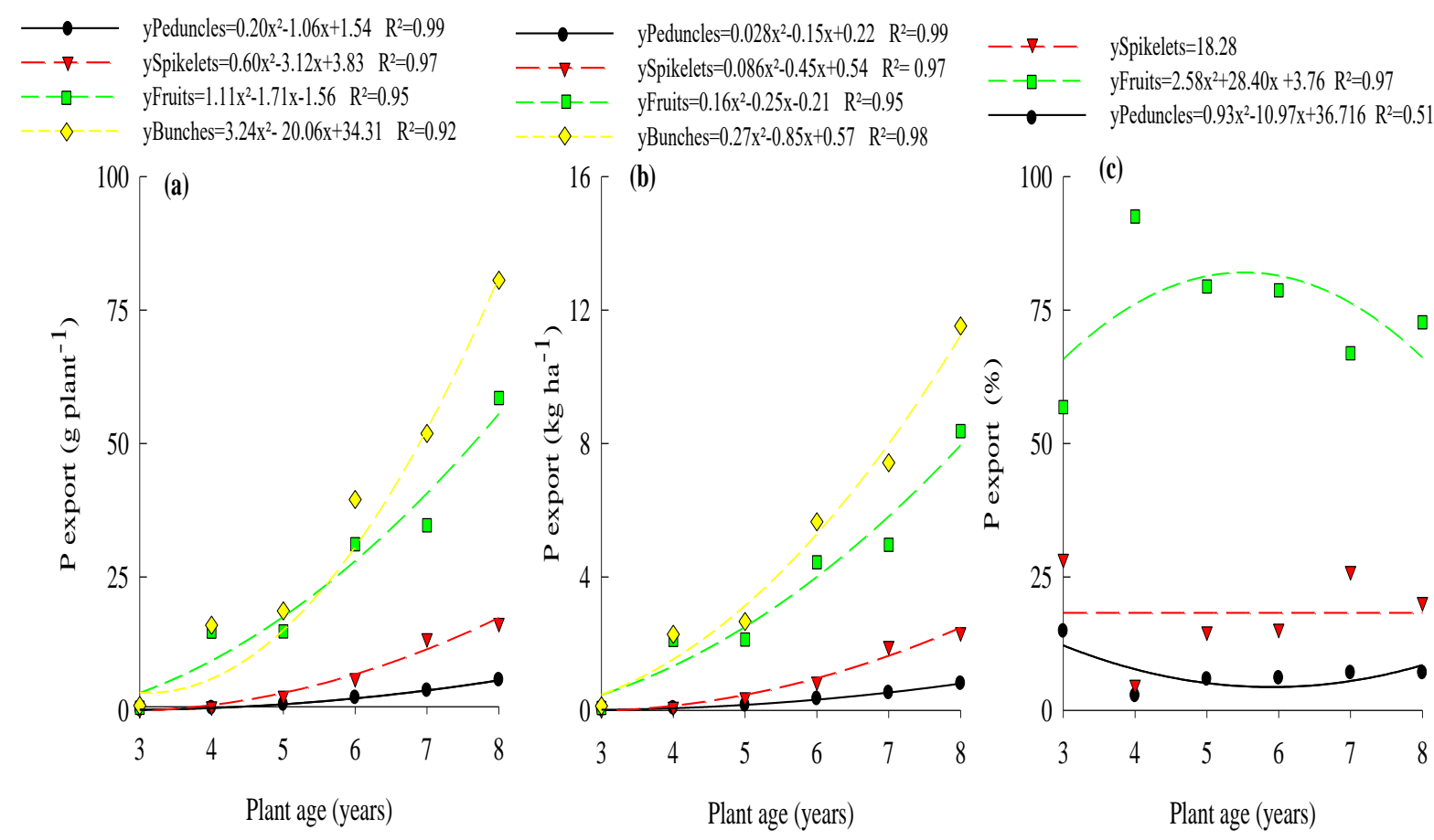

Figure 7. Export (a, b) and percentage distribution (c) of $\mathrm{P}$ in peduncles, spikelets, fruits, and bunches according to oil palm age

$\mathrm{P}$ amounts increased with plant growth and reached the maximum value of the amount extracted $\left(59 \mathrm{~kg} \mathrm{ha}^{-1}\right)$, immobilized $\left(24 \mathrm{~kg} \mathrm{ha}^{-1}\right)$, recycled $\left(23 \mathrm{~kg} \mathrm{ha}^{-1}\right)$, and exported $\left(12 \mathrm{~kg} \mathrm{ha}^{-1}\right)$ in the eighth year of age (Figure 8). 


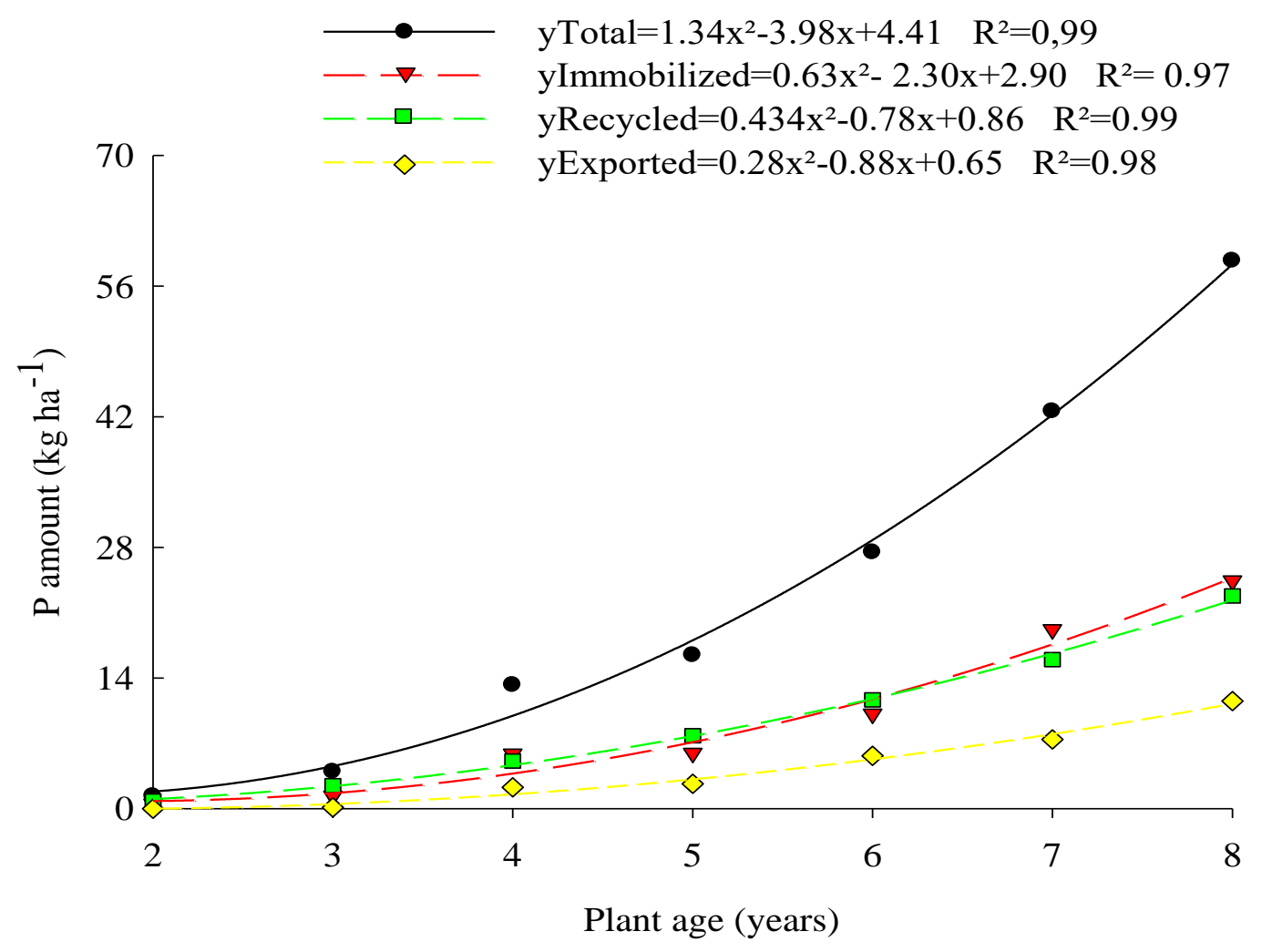

Figure 8. Amounts of P immobilized, recycled, exported, and total, according to oil palm age

\section{Discussion}

In general, older plants showed higher P concentrations in the organs (Figure 2), probably due to a more extensive root system, which provides a greater contact area with the soil. Thus, absorption of $\mathrm{P}$ applied as fertilizer (Table 2), a little mobile ion in the soil (NOVAIS et al., 2007), is entirely related to root length (BUCHER et al., 2018). In addition, higher P levels were applied to older plants (Table 2), which resulted in higher P concentrations in the soil (Table 1) and, consequently, greater absorption by older plants (Figures $2 \mathrm{a}$ and 2b). Matsumoto et al. (2008) analyzed oil palm in terms of age and observed higher $\mathrm{P}$ concentrations in leaflets $\left(4.34 \mathrm{~g} \mathrm{~kg}^{-1}\right)$ and petioles $\left(4.92 \mathrm{~kg} \mathrm{~g}^{-1}\right)$ in the third year. Bachy (1965) also found an increase in the $\mathrm{P}$ concentration in leaflets (leaf 17) according to oil palm age, corroborating our results. Haron et al. (2000) found that young oil palm plants absorbed between 10 and $20 \%$ of total P.

Levels of $\mathrm{P}$ in leaf 17 of the oil palm are considered appropriate of $1.5 \mathrm{~g} \mathrm{~kg}^{-1}$ (OCHS and OLIVIN, 1977), from 1.5 to $1.9 \mathrm{~g} \mathrm{~kg}^{-1}$ (UEXKULL and FAIRHURST, 1991), from 1.6 to $2.0 \mathrm{~g}$ $\mathrm{kg}^{-1}$ (MATOS et al., 2016), and from 1.5 to $1.8 \mathrm{~g} \mathrm{~kg}^{-1}$ (VELOSO et al., 2020). Lower P concentrations are observed in leaflets of oil palm trees of different ages (Figure 2a), which indicates $\mathrm{P}$ deficiency in the plants evaluated. The acidic soil $\mathrm{pH}$ (Table 1), due to lack of liming and high rainfall levels in the region (Figure 2), influences $\mathrm{P}$ absorption (MEURER, 2007). The $P$ transport in the soil towards the roots occurs predominantly by diffusion; therefore, $\mathrm{P}$ supply in sandy soils is reduced (Table 2) due to lower water retention capacity (MEURER, 2007). 
Possibly, the lowest $\mathrm{P}$ concentrations in reproductive organs of older plants (8 years of age) occurred due to the increase in the yield of bunches, varying from 1.5 to $20.0 \mathrm{t} \mathrm{ha}^{-1}$ (Table 2). The highest $\mathrm{P}$ concentration in the reproductive organs occurred in male inflorescence (Figure 2c). $\mathrm{Ng}$ et al. (1969) reported a high $\mathrm{P}$ concentration $\left(3.2 \mathrm{~g} \mathrm{~kg}^{-1}\right)$ in male inflorescences, corroborating our results. Plant age and $\mathrm{P}$ availability in the soil influence $\mathrm{P}$ concentrations in plants (BATES, 1971; MARSCHNER, 2012). According to Mengel and Kirkby (1982), P mobility occurs in the phloem, translocated to younger tissues by root absorption or by its redistribution from older organs to growing regions.

Variation of $\mathrm{P}$ concentrations was higher in palm heart (Table 3). Viegas et al. (2020) evaluated $\mathrm{Cl}$ in oil palm and observed greater variation in $\mathrm{P}$ concentrations in palm heart of plants. According to the authors, these variations alter plant metabolism and, consequently, the absorption rates of nutrients. Due to the beginning of the vegetative development, production is still relatively low (6 to $8 \mathrm{t} \mathrm{ha}^{-1}$ year $^{-1}$ of bunches) and increases gradually when the plants reach 8 years of age, reaching a maximum yield of 20 to $30 \mathrm{tha}^{-1}$ year $^{-1}$ of bunches.

The increase in $\mathrm{P}$ accumulation in plants from 2 to 8 years of age (Figure 3) was probably influenced by DM production from different organs, as reported by Viegas et al. (2001). Approximately 45 to $50 \%$ of DM production is allocated to the growth of male inflorescences and bunches in productive oil palm plants (CORLEY et al., 1971). Vegetative and reproductive growth are limited at source and competition occurs between different collectors, despite the priority to vegetative growth (CORLEY and TINKER, 2016).

The crown, the second largest component in P accumulation (Figure 3), influences nutrient cycling, as deposition of its organs on the soil between crop rows provides a nutrient return (VIEGAS et al., 2001). The decomposition of oil palm leaves allows distribution of $\mathrm{P}(63 \%)$, $\mathrm{N}(43 \%), \mathrm{K}(76 \%)$, and $\mathrm{Mg}(60 \%)$ during 24 months of planting (KEE and CHEW, 1997). The cycled P quantity $\left(21 \mathrm{~kg} \mathrm{ha}^{-1}\right.$ ) (Figure 3 ) is close to half of the recommended $\mathrm{P}$ amount $\left(47 \mathrm{~kg} \mathrm{ha}^{-1}\right)$ for oil palm cultivation at 8 years of age in Pará State (FRANZINI et al., 2020), considering the yield observed at this age (Table 2). P was added via fertilization of $384 \mathrm{~g}$ plant $^{-1}$ of $\mathrm{P}_{2} \mathrm{O}_{5}$, in the form of phosphine, to the eight-year-old oil palm (Table 2), which also contributed to P accumulation in the plants. Tajudin et al. (2020) state that the addition of fertilizers twice a year favors $\mathrm{P}$ accumulation in oil palm, especially in the young phase, which requires more P. According to Chan and Goh (1978), stores substantial amounts of nutrients in plants; nevertheless, rachis is not commonly used as a reference for $\mathrm{P}$ accumulation in palm oil. In addition, the legume Pueraria phaseoloides is commonly cultivated between oil palm rows in the region and this cover plant can cycle $18 \mathrm{~kg} \mathrm{ha}^{-1}$ of $\mathrm{P}$ at 2 years of age (PEREZ, 1997).

Fruits accumulated greater $\mathrm{P}$ amounts among the reproductive organs (Figure 4). This shows the importance of $\mathrm{P}$ in fruit formation with a direct influence on crop yield (Table 2), with harvesting and fertilization assuming relevance in $\mathrm{P}$ replacement in the soil (Table 1). According to the source-drain relationship, leaves act as a carbohydrate source for other plant compartments that preferentially accumulate P, such as roots and fruits (NOVAIS et al., 2007). For Fairhurst and Härdter (2003), nutritional differences in plant age groups can be explained because nutrients are mostly allocated for DM production of leaves in young palms, while a 
redistribution of nutrients occurs for bunches in adult palms.

There was greater total $\mathrm{P}$ accumulation $\left(59 \mathrm{~kg} \mathrm{ha}^{-1}\right)$ in the eighth year (Figure 5). Due to $\mathrm{P}$ concentration in the soil (Table 1), $55 \mathrm{~kg} \mathrm{ha}^{-1}$ of $\mathrm{P}_{2} \mathrm{O}_{5}$ were applied via phosphine in the eighth year (Table 2), which is the $\mathrm{P}$ amount close to the total extracted by plants at this age (Figure $5 b$ ); however, below recommended for the conditions in Pará State (FRANZINI et al., 2020). P is the macronutrient least extracted by oil palm (VIEGAS and BOTELHO, 2000) and in the weathered tropical soils, there is a drain of P (NOVAIS et al., 2007). According to Ker (1995), applications of large amounts of $\mathrm{P}$ fertilizers are required to provide $\mathrm{P}$ sources to weathered soils, which can adsorb the equivalent of $9.200 \mathrm{~kg} \mathrm{ha}^{-1}$ of $\mathrm{P}_{2} \mathrm{O}_{5}$ on the surface layer $(0-20 \mathrm{~cm})$ (KER, 1995). The clay fraction defines the soil as a source or as drain of $\mathrm{P}$, that is, in a highly weathered soil there is a predominance of P drain (NOVAIS et al., 2007). However, the soil in our study has medium texture (Table 1).

There was a higher percentage in total $\mathrm{P}$ extraction with increased plant age (Figure 6). In addition, oil palm showed a significant increase in $\mathrm{P}$ absorption from the second year after planting (NG, 1977). This shows that good nutrition at a young age is essential to provide an early start of crop growth and reach desired yields (RODRIGUES, 1993). Thus, adequate nutrition is crucial to prevent $\mathrm{P}$ from becoming a limiting factor for crop production, especially in Amazonian soils, which are weathered with high adsorption to $\mathrm{Fe}$ and $\mathrm{Al}$ oxides causing low P availability (NOVAIS et al., 2007), a limiting factor for plant growth (FITA et al., 2011). However, application of rock phosphate could gradually make P more available in the soil and reduce intensity of $\mathrm{P}$ losses due to unavailability reactions (RESENDE et al., 2006). Rock phosphate was the $\mathrm{P}$ source used in this study.

In the eighth year, bunches exported greater P amounts (Figure 7). Werkhoven (1965) states that oil palm bunches accumulate and export approximately half of the total P. Tampubolon et al. (1990) studied oil palm cultivated in an Oxisol in Indonesia and observed that P fixation requires application of levels initially higher than the plant needs, since the crop exports only $20 \mathrm{~kg} \mathrm{ha}^{-1}$ year $^{-1}$. The amount of $\mathrm{P}$ immobilized was high, 1.7 to 10 times greater than $\mathrm{P}$ exported (Figure 8). Tinker and Smilde (1963) conducted a study in Nigeria and reported that the amounts of $\mathrm{P}$ immobilized in oil palm were higher for stipe, leaves, bunches, and roots. $\mathrm{P}$, $\mathrm{Ca}$ and $\mathrm{Mg}$ are extracted in smaller amounts than $\mathrm{N}$ and $\mathrm{K}$ by oil palm plants (WERKHOVEN, 1965). Although the oil palm crop extracted and exported smaller P amounts (NG et al., 1968; VIEGAS and BOTELHO, 2000), P is the nutrient that mostly limits growth and yield of oil palm in the Brazilian Amazon (PACHECO et al., 1985; RODRIGUES, 1993).

\section{Conclusion}

The highest $\mathrm{P}$ concentration is found in the palm heart organ in the apical meristem, which commands plant growth and is responsible for the formation of leaves and inflorescences, as well as in the male inflorescence reproductive organ.

The $\mathrm{P}$ accumulation increases with the age of plants, with greater accumulation in fruits and stipe components, which can function as $\mathrm{P}$ stock.

Oil palm exports greater amount of $\mathrm{P}$ through bunches and $\mathrm{P}$ exports increase with plant age. 


\section{Al Macrothink}

Journal of Agricultural Studies

ISSN 2166-0379

2021, Vol. 9, No. 3

The amount of immobilized and recycled $\mathrm{P}$ is greater than that exported by oil palm, which is desirable, as it reduces $\mathrm{P}$ removal through bunches.

\section{Acknowledgments}

The authors wish to thank Agropalma Company for consenting to the research, Luiz de Queiroz College of Agriculture, where chemical analyses of plant tissues were carried out, researcher Sonia of the Embrapa Amazônia Oriental, and Professor Ronaldo Ivan Silveira (in memoriam).

\section{References}

Bachy, A. (1965). Diagnostic foliaire du palmier à huile - influence de $1^{\circ}$ age des arbes. Olégineux, Paris, 20(4), 277-30.

Bates, T. E. (1971). Factors affecting critical nutrient concentrations in plants and their evaluation: a review. Soil Sciense, $\quad$ (112), 116130 https://doi.org/0.1097/00010694-197108000-00005

Bucher, C. A, Bucher, C. P. C., Araújo, A. P, \& Sperandio, M. V. L. (2018). Fósforo. In: M. S. Fernandes, R. Souza, \& L. A Santos. (Eds.), Nutrição mineral de plantas (pp. 401-427). Viçosa-Minas Gerais: SBCS.

Chan, K. W. \& Goh, K. H. (1978). Interpretação de dados de folha para dendê. In: Mokhtaruddin, \& H. Aminuddin (Eds.), Métodos analíticos de solo e folha (pp. 78-95). Sociedade Malaia de Ciência do Solo, Kuala Lumpur.

Corley, R. H. V. \& Tinker, P. B. (2016). The Oil Palm. (5rd ed.) New York: John Wiley \& Sons. 692p. https://doi.org/10.1002/9781118953297

Corley, R. H. V., Hardon, J. J., \& Tan, G. Y. (1971). Analysis of growth of the oil palm (Elaeis guineensis Jacq.). Estimation of growth parameters and application in breeding. Euphytica, 20(2), 307-315 https://doi.org/10.1007/BF00056093

Cruz filho, D., Viegas, I. J. M., Galvão, J. R., Silva, D. R., Pacheco, M. J.B., Souza, F. J. L., Almeida, G. V., \& Barata Junior, V. P. (2019). Biometria e produção de palma de óleo no município de Castanhal (PA). Ibero-Americana de Ciências Ambientais, 10(4), 83-96 https://doi.org/10.6008/CBPC2179-6858.2019.004.0007

Fairhurst, T., \& Härdter, R. (2003). Oil palm: Management for large and sustainable yields. Singapore: Potash \& Phosphate Institute of Canada, International Phophate Institute (IPI, Basel).

Fernandes, R. A., Fonseca, M. R., \& Martins, A. S. B. (2013). Produtividade de feijão caupi em função da calagem e fósforo. Revista Caatinga, 26(4), 54-62.

Ferreira, D. F. (2011). Sisvar: a computer statistical analysis system. Ciência $e$ agrotecnologia, 35(6), 1039-1042. https://doi.org/10.1590/S1413-70542011000600001 


\section{Macrothink}

Fita, A., Nuez, F., \& Picó, B. (2011). Diversidade na arquitetura radicular e resposta à deficiência de $\mathrm{P}$ em mudas de L. Cucumis melo. Euphytica, 181, 323-339. https://doi.org/10.1007/s10681-011-0432-z

Franzini, V. I., Matos, G. M. B., Machado, D. N., Assunção, E. A., Viegas, I. J. M., \& Botelho, S. M. (2020). Palma de óleo (Dendezeiro). In: E. C. Brasil, M. S. Cravo, \& E. J. M Viegas (Eds.), Recomendações de adubações e calagem para o estado do Pará (pp. 279-282). Brasília: Embrapa.

Gama, J. R. N. F., Valente, M. A., Oliveira Junior, C., Cravo, M. S., Carvalho, E. J. M., \& Rodrigues, T. E. (2020). Solos do estado do Pará. In: E. C Brasil, M. S. Cravo, \& E. J. M. Viegas (Eds), Recomendações de adubações e calagem para o estado do Pará, (pp. 25-46). Brasília: Embrapa.

Haron, K., Zakaria, Z., \& Anderson, J. M. (2000). Ciclagem de nutrientes em uma plantação de dendê: os efeitos das práticas de manejo de resíduos durante o replantio sobre a matéria seca e a absorção de nutrientes por palmeiras jovens. Journal of Oil Palm Research, 12(2), 29-37. https://doi.org/10.1590/S0100-204X2007000900008

Homma, A. K., \& Rebello, F. K. (2020). Aspectos econômicos da adubação e da calagem na Amazônia. In: E. C. Brasil, M. S, Cravo, \& E. J. M. Viegas. (Eds.) Recomendações de adubações e calagem para o estado do Pará, (pp 185-204). Brasília, Embrapa.

Kee, K. K., \& Chew, O. S. (1997). Nutrients Recycled From Pruned Fronds In Mature Oil Palm (Elaeis Guineensis Jacq.). In: T. E. A. Ando. (Eds.), Plant Nutrition for Sustainable Food Production and Environment. (pp. 601-602). Dordrecht: Kluwer Academic Publishers. https://doi.org/10.1007/978-94-009-0047-9_192

Ker, J. C. Mineralogia, sorção e dessorção de fosfato, magnetização e elementos traços de Latossolos no Brasil (1995). Tese (Doutorado em nutrição de plantas) - Universidade Federal de Viçosa. Viçosa-MG, 1995. 181p.

Khan, M. S., Zaidi, A., Ahemad, M., Oves, M., \& Wani, P. A. (2010). Plant growth promotion by phosphate solubilizing fungi: current perspective. Arch Agron Soil Science, 56(1), 73-98. https://doi.org/10.1080/03650340902806469

Lebid, T., \& Henkes, J. A. (2015). Óleo de dendê na produção de biodiesel: um estudo de caso das vantagens e desvantagens econômica, ecológica e social da cultura desta oleaginosa para a produção de biodiesel. Revista gestão e sustentabilidade ambiental, 4(1), 416-447. https://doi.org/10.19177/rgsa.v4e12015416-447

Lopes, A. S., \& Guilherme, L. R. G. (2007). Fertilidade do solo e produtividade agrícola. In: R. F. Novais, V. H. Alvarez, N. F. Barros, R. L. F. Fontes, R. B. Canturutti, \& J. C. L. Neves (Eds.), Fertilidade do Solo. (pp. 1-64). SBCS: Viçosa- MG: SBCS.

Malavolta, E., Vitti, G. C., \& Oliveira, A. S. (1997). Avaliação do estado nutricional das plantas: princípios e aplicações (2rd ed.). Piracicaba: Potafos. 329p. 
Marschner, H. (2012). Mineral nutrition of higher plants (3rd ed.). New York, Academic Press. 649p.

Matos, G. S. B., Fernandes, A. R., \& Wadt P. G. S. (2016). Níveis críticos e faixas de suficiência de nutrientes derivados de métodos de avaliação do estado nutricional da palma-de-óleo. Pesquisa Agropecuária Brasileira, 51(9), 1557-1567 https://doi.org/10.1590/s0100-204x2016000900055

Matsumoto, M., Osaki. M., Nuyim, T., Jongskul, A., Eam, On P., Kitaya, Y., Urayama, M., Watanabe, T., Kawamukai, T., Nakamura, T., Nilnond, C., Shinano, T., \& Tadano, T. (2008). Nutritional characteristics of sago palm and oil palm in tropical peat soil. Journal of Plant Nutrition, 21(9), 1819-1841 https://doi.org/10.1080/01904169809365526

Mengel, K., Kirkby, E. A. (2001). Principles of plant nutrition. (5rd ed.). Berne, International Potash Institute. 849p. https://doi.org/10.1007/978-94-010-1009-2

Meurer, E. J. (2007). Fatores que influenciam o crescimento e o desenvolvimento das plantas. In: R. F. Novais, V. H. Alvarez, N. F. Barros, R. L. F Fontes, R. B. Cantarutti, \& J. C. L. Neves (Eds.) Fertilidade do solo (pp. 66-90). Viçosa- Minas Gerais: SBCS.

Mohidin, H., Hanafi, M. M., Rafii, Y. M, Abdullah, S. N. A., Idris, A. S., Man, S., Idris, J., \& Sahebi, M. (2015). Determination of optimum levels of nitrogen, phosphorus and potassium of oil palm seedlings in solution culture. Bragantia, 74(3), 247-254 https://doi.org/10.1590/1678-4499.0408

Nabun, J. S., Santos, C. B., \& Carvalho, A. C. A. (2017). Dinâmicas da agricultura familiar com cultura do dendezeiro no município de Moju, na Amazônia paraense. Novos Cadernos NAEA, 20, 161-180. https://doi.org/10.5801/ncn.v20i3.3937

Nahun, J. S., Santos, L. S., \& Santos, C. B. (2020). Formação da dendeicultura na Amazônia paraense. Mercator, 19, 1-14. https://doi.org/10.4215/rm2020.e19007

Ng, S. K. (1977). Review of oil palm nutrition and managing. Scope for greater economy in fertilizer usage. Oléagineux, 32(5), 197-209.

Ng, S. K., Thaboo, S., \& Souza, P. (1969) Nutrient contents of oil palm in Malaia. Oléagineux, Paris, 24(12), 2-670.

Ning, P., Yu, P., Zhang, Y., \& Chunjian, L. (2013). Post-silking accumulation and partitioning of dry matter, nitrogen, phosphorus and potassium in maize varieties differing in leaf longevity. Field Crops Research, 144, 19-27. https://doi.org/10.1016/j.fcr.2013.01.020

Novais, R. F., Smyth, T. J., \& Nunes, F. N. (2007). Fósforo. In: R. F. Novais, V. H. Alvarez, N. F. Barros, R. L. F. Fontes, R. B. Cantarutti, \& J. C. L. Neves (Eds.) Fertilidade do solo. (pp 471-550). Viçosa-Minas Gerais: SBCS.

Ochs, R., \& Olivin, J. (1997). Le diagnostic foliaire pour le contrôle de la nutrition des échantillons foliaires. Oléagineux, Paris, 32(5), 211-213. 
Pacheco, A. R., Tailliez, B. J, Souza R. L. R., \& Lima, E. J. (1985). Les deficiences minerales du palmier à huile (E. guineensis Jacq.) dans la region de Belém, Pará (Brésil). Oléagineux, 40(6), 295-309.

Perez, P. N. L. (1997). Crescimento, concentração e conteúdo de nutrientes em Pueraria phaseoloides L. com dois anos a oito anos de idade em Latossolo Amarelo distrófico, Tailândia, Pará. Dissertação (Mestrado) - Faculdade de Ciências Agrárias do Pará, Belém, 1997.

Resende, A. V., Furtini Neto, A. E., Alves, V. M. C., Muniz. J. A., Curi, N., \& Lago, F. J. (2006). Resposta do milho a fontes e modos de aplicação de fósforo durante três cultivos sucessivos em solos da região do cerrado. Ciência e Agrotecnologia, 30(3), 458-466 https://doi.org/10.1590/S1413-70542006000300011

Rodrigues, M. R. L. Resposta do dendezeiro (Elais guineenses Jacq.) à aplicação de fertilizantes nas condições do médio Amazonas. Dissertação (Mestre em solos e nutrição de plantas) - Escola Superior de Agricultura "Luiz de Queiroz") - Universidade de São Paulo. Piracicaba-SP, 1993, 91p.

Rodrigues, T. E., Silva, J. M. L., Silva, B. N. R., Valente, M., Gama, J., Santos, E. S., Rollim P. A. M., \& Ponte, F. C. (2005). Caracterização e classificação dos solos do município de Tailândia, estado do Pará. Embrapa Amazônia Oriental, Belém- PA. Disponível:<https://www.infoteca.cnptia.embrapa.br/infoteca/bitstream/doc/1034187/1/DOC 230.pdf.>. Acessado em 03 de março de 2021.

Santos, H. G., Jacomine, P. K. T., Anjos, L. H. C., Oliveira, V. A., Lumbreras, J. F., Coelho, M. R., ... Cunha, T. J. F. (2018). Sistema Brasileiro de Classificação de Solos. (5rd ed.) Brasília, DF: Embrapa, 2018. 356 p.

Shen, J. Yuan, L., Zhang, J., Li, H., Bai., Z., Chen, X., Zhang, W., \& Zhang, F. (2011) Phosphorus Dynamics: From Soil to Plant. Plant Physiology, 156, 997-1005. https://doi.org/10.1104/pp.111.175232

Tajudin, N. S., Musa, M. H., Seman, I. A., Aini, N., \& Amri, C. (2020). Quantifying the spatial variability of the soil and nitrogen sheet, e potassium phosphorus of rotten basal stem infectedoil panels using geospatial information system. Journal of Oil Palm Research, 32(3), 427-438. https://doi.org/10.21894/jopr.2020.0047

Tampubolon, F. H., Daniel, C., \& Ochs, R. (1990). Reponses du palmmier à huile aux fumares azotées et phosphorées à Sumatra. Olégineux, Paris, 45(11), 475-84.

Tan, N. P., Zaharah, A. R., Akma, A. S. N., \& Jamaluddin, N. (2010). Evaluating the Variability of Gafsa Phosphate Rock Uptake by Oil Palm Genotypes at Nursery Stage. Journal of Tropical Agricultural Science, 33(2), 223-231.

Tinker, P. B. H., \& Smilde, K. W. (1963). Dry-matter production and nutriente content of plantation oil palms in Nigeria. Planta and Soil, The Hague, 19(3), 3-350. https://doi.org/10.1007/BF01379488 
Uexkull, H. R. V., \& Fairhust, T. H. (1991). Fertilizing for hight yield and quality: The oil palm. International Potash Institute. Bern/Switzerland

Veloso, C. A. C., Botelho, S. M., Viegas, I. J. M., \& Rodrigues, J. E. L. F. (2020). Amostragem e diagnose foliar. In: E. C. Brasil, M. S. Cravo, \& E. J. M. Viegas. (Eds.) Recomendações de adubações e calagem para o estado do Pará, (pp. 65-72) Brasília: Embrapa.

Viegas, I. J. M., \& Botelho, S. M. (2000). Nutrição e adubação do dendezeiro. In: I. J. M., Viegas, \& A. A. Muller. (Eds.) A cultura do dendezeiro na Amazônia brasileira. (pp. 229-273). Belém, PA: Embrapa Amazônia Oriental.

Viegas, I. J. M., Conceição, H. E. O., Botelho, S.M., Frazão, D. A. C., Pimentel, M. J. O., \& Thomaz, M. A. A. (2001). Crescimento e produção de matéria seca em diferentes partes de dendezeiro, dos 2 aos 8 anos de idade. Ciências Agrárias, 36, 67-81.

Viegas, I. J. M., Galvão, J. R., Silva, A. O., Conceição, H. E. O, Pacheco, M. J. B., Viana, T. C., Ferreira, E. V. O., \& Okumura, R. S. (2020). Chlorine Nutritionof Oil Palm Tree (Elaeis guinq Jacq) in Eastern Amazon. Journal of Agricultural Studies, 8(3), 704-720. https://doi.org /10.5296/jas.v8i3.16243

Werkhoven, J. (1965). Fertilizacion de la palmera de aceite. Hanover, Velags Gesellschaft Ackerbau.Disponível: $<$ http://www.sidalc.net/cgi-bin/wxis.exe/?IsisScript=UACHBC.xis\&me thod $=$ post $\&$ formato $=2 \&$ cantidad $=1 \&$ expresion $=m f n=058536>$. Acesso em 15 de fevereiro de 2021.

Woittiez, L. S., Wijk, M. V., Slingerland, M., Noordwijk, M. V., \& Giller, K. E. (2017). Yield gaps in oil palm: A quantitative review of contributing factors. Europ. J. Agronomy, 83, 57-77. https://doi.org/10.1016/j.eja.2016.11.002

\section{Copyright Disclaimer}

Copyright for this article is retained by the author(s), with first publication rights granted to the journal.

This is an open-access article distributed under the terms and conditions of the Creative Commons Attribution license (http://creativecommons.org/licenses/by/4.0/). 